\title{
Radiographic examination in the diagnosis of a curious case associating odontoma to agenesis and supernumerary teeth
}

\author{
O exame radiográfico no diagnóstico de um caso \\ curioso associando odontoma à agenesia \\ e dente supranumerário
}

\author{
Jéssica de Oliveira Alvarenga FREIRE ${ }^{1}$ iD https://orcid.org/0000-0002-5891-8637 \\ Giovanna de Souza BIANCO1 ID https://orcid.org/0000-0002-1705-1897 \\ Thais Sumie Nozu IMADA² iD https://orcid.org/0000-0002-8885-3029 \\ Leda Maria Pescinini SALZEDAS ${ }^{1}$ iD https://orcid.org/0000-0001-9017-0473 \\ Carla Renata Sanomiya IKUTA ${ }^{1}$ iD https://orcid.org/0000-0002-9281-9106
}

\section{ABSTRACT}

Developmental disorders of human dentition may result in various abnormalities according to etiologic agents and the developmental period involved. The size, shape and number of teeth may be affected. Dental abnormalities can occur singly or in multiples in an individual and may or may not be associated with syndromes. Complementary radiographic examinations are valuable for diagnosis, especially in lesions that are asymptomatic and detected only through examination. The present study is intended to report a case of an incidental finding in panoramic radiography of an odontoma, a supernumerary tooth and permanent tooth agenesis in the same non-syndromic individual. According to the literature, the association of hypodontia and hyperdontia (called concomitant hypo-hyperdontia) is most common. The association of hyperdontia and odontoma is uncommon but still reported. However, regarding the association of hypodontia and odontoma no reports were found, as well as the association of the three pathologies.

Indexing terms: Anodontia. Tooth abnormalities. Tooth, supernumerary.

\section{RESUMO}

Os distúrbios de desenvolvimento da dentição humana podem resultar em diferentes anomalias dependendo do agente etiológico e do período do desenvolvimento acometido. O tamanho, a forma e o número dos dentes, dentre outros, podem ser afetados. Podem ocorrer isoladamente ou em conjunto num mesmo indivíduo, bem como estarem ou não associados a síndromes. Os exames radiográficos complementares são valiosos para o diagnóstico, sobretudo quando as lesões são assintomáticas e detectadas incidentalmente no exame. O presente trabalho relata o caso de achado incidental, em radiografia panorâmica, de odontoma, dente supranumerário e

$\boldsymbol{\nabla} \nabla \boldsymbol{\nabla}$

1 Universidade Estadual Paulista "Júlio de Mesquita Filho", Faculdade de Odontologia de Araçatuba, Departamento de Patologia e Propedêutica Clínica. Rua José Bonifácio, 1193, Araçatuba, SP, Brasil. Correspondence to: JOA Freire E-mail: <je.oafreire@gmail.com>.

${ }^{2}$ Centro Universitário da Grande Dourados. Dourados, MS, Brasil.

$\boldsymbol{\nabla} \boldsymbol{\nabla} \boldsymbol{\nabla}$

How to cite this article

Freire JOA, Bianco GS, Imada TSN, Salzedas LMP, Ikuta CRS. Radiographic examination in the diagnosis of a curious case associating odontoma to agenesis and supernumerary teeth. RGO, Rev Gaúch Odontol. 2021;69:e20210048. http://dx.doi.org/10.1590/1981-863720210004820200006 
agenesia de dente permanente num mesmo indivíduo não sindrômico. Segundo relatos da literatura, a associação de hipodontia e hiperdontia, denominada hipo-hiperdontia concomitante, é a mais comumente encontrada. A associação de hiperdontia e odontoma é incomum, mas ainda é relatada. No entanto, a respeito da associação de hipodontia e odontoma não foram encontrados relatos, bem como da associação das três patologias.

Termos de indexação: Anodontia. Anormalidades dentárias. Dente supranumerário.

\section{INTRODUCTION}

Odontomas are benign mixed odontogenic tumors formed by odontogenic tissues in various degrees of differentiation arranged in a disorganized way. Although they are still classified by the World Health Organization (WHO) as tumors, many authors consider them hamartomas instead of true neoplasm, due to their behavior being atypical of tumor lesions, as they do not evolve in size until development and do not invade adjacent tissues [1].

Odontomas are classified into two types - complex and compound - according to the degree of structural organization of the tissues. While composite odontomas have tooth-like structures, complex odontomas are amorphous masses of disorganized odontogenic tissue [1]. Hyperdontia and hypodontia are conditions that affect the number of teeth, the first being an increase in the normal number and the second a reduction. Excessive teeth are called supernumerary teeth and classified according to shape and size into supplemental teeth (when they are of normal size and shape) and rudimentary (when they present abnormal size and shape) $[2,3]$.

Dental anomalies may occur alone or in combination and affects more syndromic patients often [4]. Functional and aesthetic consequences are observed, such as disturbances of dental eruption and malocclusion, and these anomalies may also undergo pathological transformations of the dental tissues $[5,6]$. They are mostly asymptomatic and, therefore, often diagnosed incidentally during routine radiological examinations. The present study aims to report a case of incidental finding in a panoramic radiography of complex odontoma, supernumerary tooth and permanent tooth agenesis in the same individual.

\section{CASE REPORT}

An asymptomatic, non-syndromic 19-year-old woman was referred by a private dental surgeon to a radiological center for a panoramic radiograph to plan the extraction

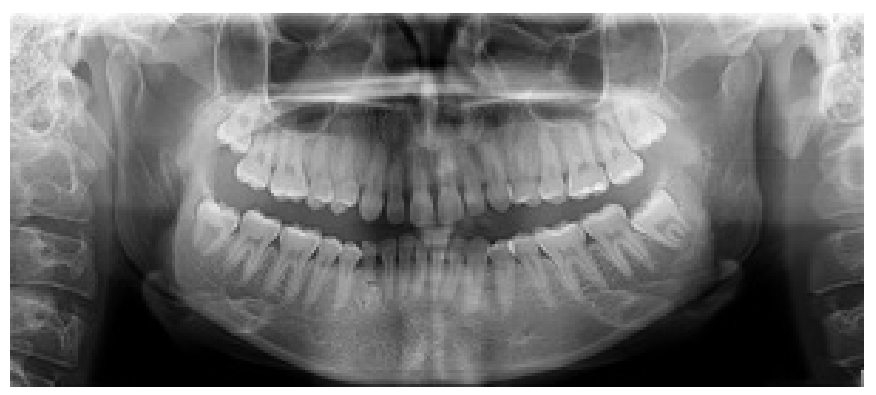

Figure 1. Panoramic radiography of the patient.

Table 1. Case reports with or without hyperdontia, hypodontia and odontoma in the mandible.

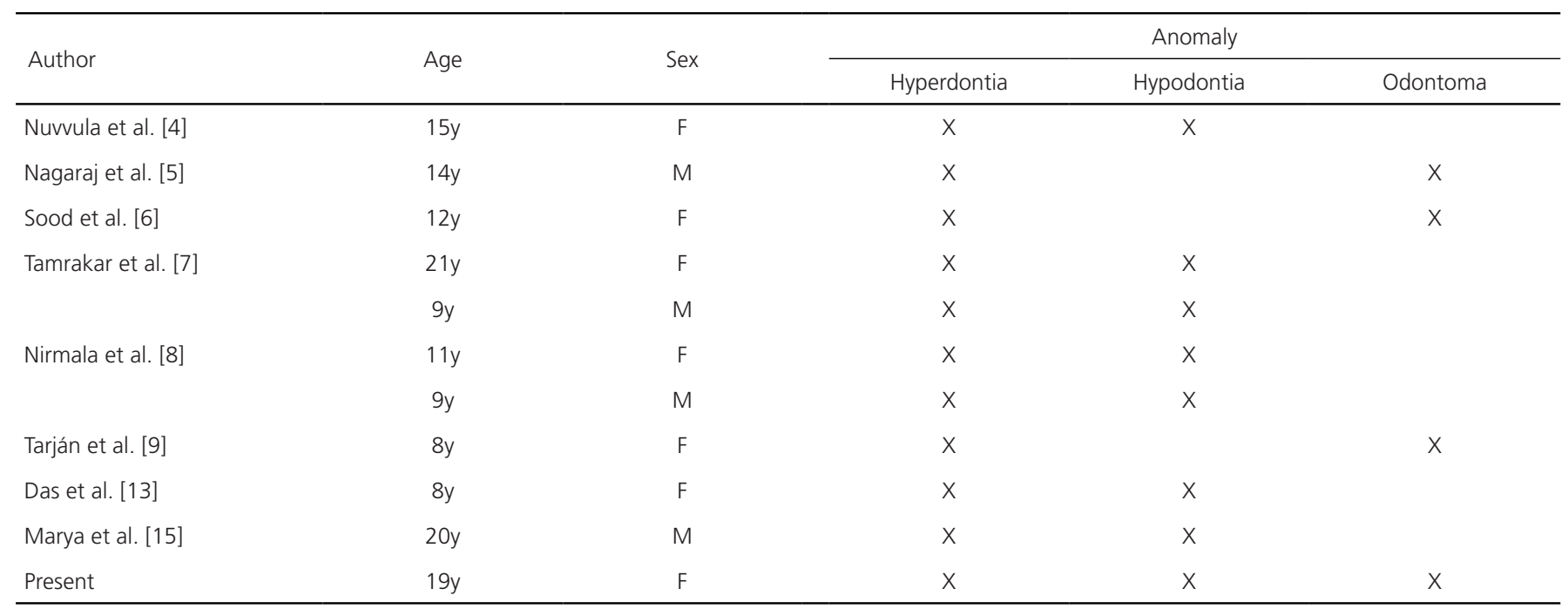


of third molars and assess the persistence of dental element 83. Panoramic radiography (figure 1) presented a supplementary supernumerary tooth of 41 , agenesis of 43 and persistence of 83 , and a complex odontoma adjacent to the apical region of 83 was observed. The attending dentist was informed of the presence of anomalies.

\section{DISCUSSION}

The simultaneous occurrence of odontoma, a supernumerary tooth and agenesis of a permanent tooth with persistence of the deciduous tooth in the same region of the same quadrant in the jaw has not been reported previously. However, associations between hyperdontiaodontoma and hiperdontia-hipodontia have been reported. The association of hyperdontia and hypodontia is more common, but only five cases were identified in which, as in the present case, both anomalies were found in the mandible, the most unusual situation $[3,4,7,8]$ (table 1 ). Agenesis of third molars was excluded. Nevertheless, all cases describe an occurrence in the anterior region of the mandible, in which agenesis affected the central incisors and the supernumerary tooth was a mesiodens. The occurrence of hyperdontia in the anterior region of the mandible is rare and, when it occurs, the supernumerary teeth most commonly present a conical shape and reduced size [8], in contrast to the present case, in which the supernumerary tooth presents a normal size and shape.

There are few case reports relating hyperdontia and odontoma anomalies in the same individual, making it difficult to establish an epidemiological profile $[5,6,9]$. Regarding etiopathogenesis, according to Pippi's [1] study correlating hyperdontia and odontoma, there are some similarities among them: higher occurrence in the same regions, same complications, higher frequency in young patients, formed by completely differentiated dental tissues and similar immunohistochemical and genetic characteristics. The only epidemiological difference was the male preference in hyperdontia and the absence of predilection for sex in odontoma.

Although classified as a tumor, odontoma can be considered a hamartoma, just like supernumerary teeth. Thus, the pathological process of both can be compared, since genetic and/or environmental stimuli can cause hyperactivity of the dental blade, resulting in structures with different degrees of morphodifferentiation [1].
The association of hyperdontia and hypodontia, called concomitant hypo-hyperdontia $(\mathrm{CHH})$, unlike the others, is more reported in the literature. $\mathrm{CHH}$ has a prevalence of 0.002 to $0.31 \%$, affecting younger people ranging in age from the 1st to the 3rd decade of life, and has no predilection for sex $[2,3,10,11,12]$. The bimaxillary type is more common, and mandibular occurrence is the least common $[3,4,7,8]$. While hyperdontia and hypodontia represent opposing pathological processes, it has been suggested that disorders of migration, proliferation and differentiation of neural crest cells and interactions between epithelial and mesenchymal cells during the onset of odontogenesis may explain these conditions $[2,13,14]$.

These three changes identified in the present case may be representations of the same pathological process caused by genetic alterations and/or environmental factors in the dental lamina and adjacent ectomesenchyme during odontogenesis. The etiopathogenesis is still not completely understood, as well as whether there is a relationship between the development of various anomalies in the same individual. However, it is known that these changes are related to the area and the time of occurrence.

The asymptomatic characteristics, for the most part, of hypodontia, hyperdontia and odontoma explains incidental diagnosis in routine radiological exams, as occurred in the case reported.

\section{CONCLUSION}

The triple odontoma-agenesia-supernumerary association presented is rare and not yet reported in the literature. The accomplishment of complementary radiographic examinations is essential for the diagnosis and adequate treatment planning of these asymptomatic lesions and the follow up. In addition, a clinician has the responsibility to interpret the examination completely and identify possible changes in normality, even if they are not the reason for the examination, thus contributing to the diagnosis of lesions, even if asymptomatic.

\section{Collaborators}

JOA FREIRE, GS BIANCO, conception and project; analysis and interpretation of data; article writing or relevant critical review of intellectual content. TSN Imada, acquisition, analysis and interpretation of data. LMP SALZEDAS, relevant 
critical review of intellectual content; Final approval of the version to be published. CRS IKUTA, Conception and project; Relevant critical review of intellectual content; Final approval of the version to be published.

\section{REFERENCES}

1. Pippi R. Odontomas and supernumerary teeth: is there a common origin? Int J Med Sci. 2014;11(12):1282-1297. http://dx.doi.org/10.7150/ijms.10501

2. Anthonappa RP, Lee CK, Yiu CKY, King NM. Hypohyperdontia: literature review and report of seven cases. Oral Surg Oral Med Oral Pathol Oral Radiol Endod. 2008;106(5):e24-e30. http://dx.doi.org/10.1016/j.tripleo.2008.07.012

3. Mallineni SK, Nuvvula S, Cheung ACH, Kunduru R. A comprehensive review of the literature and data analysis on hypo-hyperdontia. J Oral Sci. 2014;56(4):295-302. http://dx.doi. org/10.2334/josnusd.56.295

4. Nuvvula S, Kiranmayi M, Shilpa G, Nirmala SVSG. Hypohyperdontia: Agenesis of three third molars and mandibular centrals associated with midline supernumerary tooth in mandible. Contemp Clin Dent. 2010;1(3):136-41. http://dx.doi.org/10.4103/0976-237X.72775

5. Nagaraj K, Upadhyay M, Yadav S. Impacted maxillary central incisor, canine, and second molar with 2 supernumerary teeth and an odontoma. Am J Orthod DentofacialOrthop. 2009;135(3):390-9. http://dx.doi.org/10.1016/j.ajodo.2006.12.023

6. Sood PB, Patil B, Godhi S, Shetty DC. Multiple supernumerary teeth and odontoma in the maxilla: A case report. ContempClin Dent. 2010;1(1):45-6. http://dx.doi.org/10.4103/0976-237X.62528

7. Tamrakar AK, Rathee M. A Rare Occurrence of Non-Syndromic Hypo-Hyperdontia in the Mandibular Anterior Region. J Clin Diagn Res. 2014;8(8):ZL01-2. http://dx.doi.org/10.7860/ JCDR/2014/9401.4726
8. Nirmala SVSG, Sandeep C, Nuvvula S, Mallineni SK. Mandibular hypo-hyperdontia: A report of three cases. J Int Soc Prev Community Dent. 2013;3(2):92-6. http://dx.doi. org/10.4103/2231-0762.122451

9. Tarján I, Gyulai SG, Soós A, Rózsa N. Tuberculate and Odontoma Type Supernumerary Teeth. J Craniofac Surg. 2005;16(6):1098-102. http://dx.doi.org/10.1097/01.scs.0000179748.83541.c4

10. Schmitd LB, Assao A, Ramalho-Ferreira G, Faverani LP, Oliveira DT. An Uncommon Occurrence of Three-Fourth Molars Concomitant to Hypodontia in a Nonsyndromic Patient. J Craniofac Surg. 2017;28(2):482-3. http://dx.doi.org/10.1097/ SCS.0000000000003322

11. Gokkaya B, Kargul B. Prevalence of concomitant hypohyperdontia in a group of Turkish orthodontic patients. Eur Arch Paediatr Dent. 2016;17:53-7. http://dx.doi.org/10.1007/ s40368-015-0201-0

12. Varela M, Arrieta P, Ventureira C. Non-syndromic concomitant hypodontia and supernumeraryteeth in an orthodontic population. Eur J Orthod. 2009;31(6):632-7. http://dx.doi. org/10.1093/ejo/cjp046

13. Das G, Sarkar S, Bhattacharya B, Saha N. Coexistent partial anodontia and supernumerary tooth in the mandibular arch: a rare case. J Indian Soc Pedod Prev Dent. 2006;24(5):S33-4.

14. Sharma A. A rare case of concomitant hypo-hyperdontia in identical twins. J Indian Soc Pedod Prev Dent. 2008;26(6):S79-81.

15. Marya CM, Sharma G, Parashar VP, Dahiya V, Gupta A. Mandibular midline supernumerary tooth associated with agenesis of permanent central incisors: A diagnostic conundrum. Stomatologija. 2012;14(2):65-8.

Received on: 1/2/2020 Final version resubmitted on: 17/4/2020 Approved on: 3/6/2020 